\title{
Islamic Education: Potential Tool in Reducing Religious Syncretism among Muslims in Yoruba Land
}

\author{
Balogun Muhsin Adekunle \\ Adeniran Ogunsanya College of Education, Nigeria
}

\begin{abstract}
Different disciplines have explored the history of Islam in Yoruba land which started in the early $18^{\text {th }}$ Century. However, the role of Islamic Religious education in reducing the phenomenon of religious syncretism has not been systematically studied. Therefore, this article examines the extent of the involvement of Yoruba Muslims in syncretic beliefs and practices in Nigeria using the Lagos state as a case study, with a view to bringing out the impact of religious education through (the unity of Allah) Tawhid on them. This paper notes that there is prevalence of religious syncretism among many Yoruba Muslims and argues that the impact affects them negatively; if continuous awareness campaign and Islamic religious education could be rigorously carried out the phenomenon will be reduced. Both primary and secondary sources were used to obtain information on this paper. This paper argues that the impact of Tawhid and religious education is not yet much inculcated into many Yoruba Muslims owing to many reasons. Therefore, a concerted effort is necessary among all the Muslim scholars, Imam, and government in the task of reducing the negative impacts of religious syncretism
\end{abstract}

\section{Introduction}

The meaning of Islam is yielding and submission to Allah. The holy prophet Muhammad (SAW) explained that the word Islam was the name of the five basic pillars of Sharia the (Law of Islam).

Islam is a way of life, we must not have the erroneous idea that since Islam is a way of life, and it is securer. No, Islam means a religion of ease, which does not create hardship or difficulty for its adherents. The key or salient word of Islam is peace.

Islamic education is an education which trains the sensibility of pupils in such a manner that in their attitude of life, their actions, decisions and approaches to all kinds the spiritual are deeply felt the ethical values of Islam. They are trained mentally, so disciplined, that they count to acquire knowledge not merely to satisfy an intellectual curiosity or just for rational, righteous being that brings about the spiritual, moral, physical welfare of their families, their people and mankind. This attitude derives from a deep faith in God and a whole hearted acceptance of a God given moral code.

The necessary significance of such a code of natural development or rational and spiritual man is experienced and understood by the application of these principles in nature and society.

Islamic Studies is a subject that makes Islamic education widely known in the education curriculum of the country, a number of opinions has been expressed as regards the subject's infusion into the national Curriculum, many people feel that the inclusion of Islamic studies in the curriculum is not relevant to what the country needs now since the country needs technological advancement. The people feel that instead of producing Islamic scholars why can't the government embark on technological advancement.

Hymen conceptualizes teaching as the teacher's way of undoing the students to go give attention to learning. The teacher is expected to induce the students to give attention to acquiring knowledge. He directs their attention to what is to be learned, observes the students, and diagnoses their problem of learning. Eway opines that there is equation between teaching and learning which is between selling and buying. He further explains that a merchant who claims to have a good day must have sold a lot of goods and it the same way an effective teacher can deem to have done a good day or can apply what has been taught.

Akinpelu says teaching is the conscious and deliberate effort by a mature or experienced person to impart knowledge, information, skills attitude and belief to an immature or less experienced person to understand what is taught on rational basis [1]. The problem of teaching is a continuous process, that the teaching profession is not alternative even some of those that have been trained as teachers of Islamic studies remain in teaching because they have no other alternatives. Many young men and women in Nigeria and in Lagos state in particular do not like teaching Islamic studies as a career because it is not lucrative.

As a result of these, many trained teachers of Islamic studies size the slightest opportunity to run away from the profession either to go for further studies or never to come back again or leave the teaching profession.

However, in Nigeria educational system Islamic studies are considered as dynamic discipline and 
should be seen as such. Islamic studies is an elective subject in the senior secondary schools but it is often referred to as a compulsory subject in the junior secondary school because it form part of the call courses of Art students.

\section{Concept of Religious Syncretism}

Syncretism consists of an attempt to reconcile disparate or contradictory beliefs while melding practice of various schools of thought. It is also seen as an attempt to merge and analogize discrete traditions, especially in theology and mythology of religion. The oxford dictionary first records the word syncretism in English in 1618, derives from modern Latin syncretismus, drawing on the Greek words (synkretismos), which means "Synchronization with Crete". There are different types of syncretism, but religious syncretism is bleeding of two or more religious belief systems into a new system or incorporating into a religious tradition, beliefs from unrelated traditions.

Eric Maroney states that syncretism is simply borrowing. He also goes further to assert that syncretism occurs when one religion adopts, absorbs or otherwise accepts elements of another religion [6]. He points out that this term involves exchange and transformation. It is opposite to fundamentalism and embrace multiplicity. Maroney claims that this terminology is very complex in religion and has strange dynamics. He claims that the dictionary definition of the word implies fusion or reconciliation of differing systems of belief in religion especially when result is heterogeneous or incongruous. He suggests that although the three great Abrahamic monotheistic religions: Islam, Christianity and Judaism go against it, but none of the can claim exclusivity [7].

Shaw and Stewart assert that the different local versions of 'notionally standard world religions' such as Christianity and Islam are often pointed to as prime examples of syncretism in this critical sense, when looking at the works of missionaries and theologians [2].

The new dictionary of theology traces the history of syncretism as it was used by Plutarch, which made reference to the ability of the Creten warring factions to unite against a common enemy. But in the $17^{\text {th }}$ century it was used by Geory Calixtns (1586-1650) to seek unity among protestant denominations. It was in the $19^{\text {th }}$ century that the term was adopted by the schools of the history of religion to describe any religion that was the result of fusing two or more religions.

In this sense, syncretism in a broader sense will mean the process of borrowing elements by one religion from another in such a way as not to change the basic character of the receiving religion [4]. It is seen as 'takhlìt' in Arabic means 'mixing'. Muslim theologians define it as a practice whereby one professes Islam, performs Islamic acts such as Șal̄̄t, Sawm etc., but at the same time, engages in some practices that are opposed to fundamental beliefs of Islam, for instance, divination. They are known as syncretics or mixers (Mukhlitun) [5].

Both Imām Muhammad al-Maghili and Shaykh Uthmōm ibn Fodio gives character sketches of syncretists and deliver a verdict of infidelity on them. Shaykh Uthmōm ibn Fodio in his book Nurul $a l-B \bar{\alpha} b$ lists ten items that constitute syncretism and states that such practices and beliefs emanate from none except the disbelievers and polytheists. They include: veneration of trees and stones by offering slaughtered on them, casting cotton on stones or at the foot of the tree, putting clothes or food on tombs of the scholar as votive offering, charming people (magic of love and separation), writing the Qur, $\bar{\alpha}$. and Allah's names on filthy objectives or writing it with blood spilled during slaughter, divination diviners [8].

Some acts according to Muslim theologians are capable of shutting Muslims out of the Islamic fold. These, they assert, constitute infidelity of faith, and these acts are termed "Violations of Islam (Nawōqid al-Islām). These includes: associating partners with Allah, setting up intermediaries between oneself and Allah, magic and ridiculing or hating what the prophet brought [10].

For the purpose of this paper, our working definition will be a situation where by a person observes the tents of Islam like five pillars of Islam, the six articles of faith and at the same time still believes and practices some elements of traditional religions and customs that go against the fundamental beliefs of Islam, especially the unity of Allah.

\section{Aims and Objectives of Islamic Education}

Ayed Muhammad suggested the following as the aims and objectives of Islamic studies which will enable the learners to:

1. Perceive religion from Islamic point of view.

2. Recognize the purpose of their creation as human being.

3. Make conscious effect towards fulfilling the purpose.

4. Make conscious effort toward attaining success in this life and in the hereafter.

5. Appreciate the Islamic culture, which must be protected and preserved.

6. Put into use the interment which Islam prescribes for the Muslims towards maintaining 
normal relationship with God, the creator and coordinator of the entire universe.

With the above aims and objectives, the scope of Islamic studies curriculum is easily shaped.

The curriculum deals with the particular part of an orientation that will assist him to develop the right attitude of life that he could be useful to himself his community above all to be an obedient servant of Allah, His creator.

Sarwa defines Islamic studies as a system which transmits the acquired knowledge to the younger generation of Muslims in order to prepare them from life as a vicegerent of Allah on earth with the role or aim of achieving success in the Islamic studies could be perceived as a knowledge which is acquired in order to help the learner to develop religions and moral skills and value which help to live a meaningful life and prepare him to have a successful life in the hereafter (life after death).

\section{Factors Affecting the Study of Islamic Education}

The problems include the following

i. Poor methods of teaching

ii. Islamic studies is put under the category of minor subject in the curriculum

iii. Divorcing Arabic from Islamic studies in the curriculum

iv. Inadequate incentives for the teacher

v. Orientation of the subject toward examination success

vi. The tutor shows little concern on the subject

vii. Inadequate and insufficient Islamic studies text books

viii. Insufficient constrain revision of the syllabus

ix. Inadequate and unequal allocation of periods

\subsection{Poor Method of Teaching}

Olajide stresses that it has been observed that most teachers do not teach the students, they are always in the habit to tell the students to form note on what they teach them which is against the teaching profession.

\subsection{Islamic studies is put the category of minor subject in the curriculum}

Islamic studies as a subject is made optional under the school curriculum, this is wrong because it teaches morality, how to fear God, it also teaches generosity, brotherhood and keep man away from tribalism, nepotism, syncretism and sectionalism, more so, the National policy on education has taken away Islamic studies from the core subjects to be studied in senior secondary schools.

\subsection{Authority}

Badmus observes that authority shows little concern and obviously there are little support from the ministry of education shouldered over the teaching of Islamic studies in our school, teaching materials are not adequately supplied expect chalk board, papers, and the Islamic studies teachers are no sent to attend refresher courses or rather organize one for them which the usual norm in other subjects.

\subsection{Insufficient Incentive for the Teachers}

It is apparent that Islamic studies teaching profession suffers as a result of the following:

- Islamic studies are not given enough recognition.

- The ministry does not accord the right social status to the Islamic studies.

- Islamic studies teacher graduates from abroad or who have other certificate apart from degree are given less salaries and are also denied from fringe benefits which their other counterpart enjoys.

\subsection{Inadequate Availability of Relevant Islamic Studies textbooks}

All subjects apart from Islamic studies have adequate textbooks which guide them and direct their teaching respectively. However, the teaching of Islamic studies lapses in this lack of important instrumentation, the little methods the Islamic studies teacher learned in their previous teachers college or colleges of education are found to be less effective in the present day's system of effective teaching. These teachers therefore due to unavailability of Islamic studies textbooks find it difficult to know what to inculcate to the memory of the pupils based on this, many teachers therefore do run away from the subject and those who remain there predominantly do teach the subject theoretically. 


\subsection{Attitude of Parents to Islamic Studies as a Discipline}

Among the challenges facing the study of Islamic studies in secondary school is the lukewarm attitude of parents to Islamic studies as a discipline more than anything else, the absence of parents' attention affects the hitherto unshakeable interest, most students of Islamic studies. Some parents do not encourage their children in learning Islamic studies to the extent that the pupils realize this fact from them by not supplying those educational materials relating to Islamic studies. Furthermore, some parents prefer their children to do science rather than art subject.

\subsection{Attitude of the Government is trivial on Islamic studies as a discipline}

Other fundamental challenges facing Islamic studies are from the government, the government does not recognise the teachers and students of Islamic studies.

Aliyu Danda says "Presently the position of Islamic studies in the school curriculum is very unsatisfactory if not pathetic. This is because it is portrayed as a mere religious knowledge that government shows little interest by giving little incentives for the teachers of Islamic studies. These are where government refuses to supply suitable textbooks on the teaching of the tenets of Islamic studies to come to the aid of both the teachers and the taught. Those that are available are very few and far beyond the purse of the average youth or students and this affect the pupils.

\section{Suggested Solutions to the Problems Affecting Islamic Education among Yoruba Muslims}

There are many ways of solving the problems of teaching of Islamic studies. They include:

Balogun and Jimoh outline the way forward from student attitude to the study of Islamic studies in schools.

1. Islamic religious education should be made compulsory to Muslim children

2. Islamic organizations should be united and they should be given scholarship and other assistance to students needing Islamic religious education.
3. Islamic organizations should also establish schools which educate children and serve as a means of employment for Muslim student graduate.

4. Parents should not leave all the duties to teachers alone.

5. Government should organize workshops, seminars and refresher courses for the teachers so as to acquaint them with the modern methods of teaching and different ways of motivating the students. Teachers should be motivated by the government in order to discharge their duties effectively.

\section{How Islamic Education Could Reduce the Problem of Religious Syncretism.}

- It is recommended that more concerted efforts should be geared towards hardworking, integrated education, and reliance on Allah with wisdom and beautiful preaching.

- Individual, philanthropists, voluntary organization, and Muslim societies could come together to sponsor indigent Muslim children to proceed on courses on Tawhid, Hadith, Qur'an in Saudi Arabia, Sudan, etc. among others to study and learn more about authentic Islam.

- Islamic education and teaching against these practices should be continuous and relentless and other efforts to eradicate Syncretism among Yoruba society.

This study has pedagogical implications for parents, guardians, carers \& Muslim teachers that the teaching and the study of Islam early in life has the potentiality of reducing religious syncretism in our society.

\section{References}

[1] Akinpelu, M.B (2003). The Teaching Profession. Blessed Publisher: Orile Iganmu

[2] Charles, S. and Rosalid,S. (eds), Syncretism/ AntiSyncretism: The Politics of Religious Synthesis, London: Routledge, 1994.

[3] Droogers, A., Syncretism: The Problem of Definition, the definition of the problem in: Anton,W., Hendrick, M.,Vroom,Jerald D. Gort and Rein .F. (eds.), Dialogue and Syncretism: An interdisciplinary Approach, 
Amsterdam: William, B. Eerdmans Publishing Co, 1989, pp, 5-6

[4] Ferguson, S.B and Wright, D.F., (eds), New Dictionary of Theology, Leicester:Inter-Varsity Press, 1988.

[5] Jimoh, S.L Kufr in Broader Perspective, Lagos. The Companion, 1995.

[6] Maroney. Eric, The Encyclopedia of Religion New York: Macmillan 1987

[7] Maroney. Eric, Religious Syncretism, London, CMS Press, 2006.

[8] Ogunbiyi, I.A., Nōr $a l-B \bar{\alpha} b$-The Litmus test of Pure Islam as Interpreted by Shaykh Uthman bn. Fudi, in: Research Bulletin, Vols 18 \& 19, Ibadan: Center for Arabic Documentation, University of Ibadan, 1990-1991.

[9] Ogunbiyi, I.A., Arabic Loan words in Yoruba Language in the Light of Arabic/ Yoruba from PreHistorical Times, in: Sudan Arabic Journal Language Studies, 1984, p. 161-175.

[10] Qadhi, A.Y., Du'̄̄, An Explanation of Muhammad ibn 'Abdul- Wahhab's Four Principles of Shirk, Birminghan: Al-Hidayah Publishing and Distribution, 2002.

[11] Qadhi, A.Y., Du'̄̄, An Explanation of Muhammad ibn 'Abdul-Wahhabb's Kashf al-Shubuhat: A Critical Study of Shirk, Birminghan: Al-Hidayah Publishing and Distribution, 2003.

[12] Vroom, H. M., Syncretism and Dialogue: 'A Philosophical Analysis', in: Anton, W., Hendrik, M.V., Jerald, D.G., and Rein, F. (eds), Dialogue Syncretism: An interdisciplinary approach, Amsterdam: Willam, B. Eerdans Publishing Company, 1989, pp.27-40 